\title{
XX. An attempt to prove that the matter of heat, like other substances, possesses not only volume but gravity; being a second essay on caloric. Read before the Askesian Society November 1800
}

\section{Alexander Tilloch}

To cite this article: Alexander Tilloch (1801) XX. An attempt to prove that the matter of heat, like other substances, possesses not only volume but gravity; being a second essay on caloric. Read before the Askesian Society November 1800, Philosophical Magazine Series 1, 9:34, 158-167, DOI: $10.1080 / 14786440108562683$

To link to this article: http://dx.doi.org/10.1080/14786440108562683

$$
\text { 曲 Published online: } 18 \text { May } 2009 .
$$

Submit your article to this journal ए

\section{Џ Article views: 2}

Q View related articles ¿ 
the proportion.which this difference in the width of the gauge at its narroweft end might bear to the whole of its prefent width at the fame end, fhould be accurately afcertained to enable chemifts in different countries to obtain a uniformity in their refults.

XX. An Attempt to prove that tbe Matter of Heat, like other Subftances, poffeffes not only Volume but Gravity; being a Second Effay on Caloric. By Alexander Tilloch. Read before the Afkefan Society November 1800.

$\mathrm{I}_{\mathrm{N}}$

$\mathbf{N}$ the hafty effay read before this Society in the courfe of our laft feffion * I ventured to call in queftion the truth of certain commonly received doctrines refpecting heat or caloric, mentioned feveral facts which admit of conclufions very different from thofe which have been drawn from them to fupport the doctrines referred to ; and endeavoured to thow that heat retains uniformly the fame character, properties, and mode of action; in oppofition to thofe who contend that it is fometimes fenfible or free, and at other times latent or fixed.

I alfo endeavoured to prove that heat is a real diftinct fubftance, and not a mere quality or accident refulting from the modification of matter. I thowed, by many proofs, that it poffeffes volume, which is a characteriftic of matter; that, when expelled by chemical combinations, the volume of the compound is lefs than the fum of that of the ingredients; and that, probably, the diminution is exactly equal to the volume of the heat that has been thrown out: that, on the other hand, when the compound is increafed in volume, it has acquired, from the contiguous bodies, a portion of caloric, probably, exactly equal in volume to that increafe: and, to be brief, that the general laws enumerated in my former eflay, and which, I believe, are univerfally admitted, being fufficient to explain all the known phænomena, without having recourfe to the doctrine of latent, as diftin-

* Sec P'jilofopbicul Magazine, Vol. VIII. p. 70, I 19 , and 3 Ix.

guifhed 
guilhed from free beat, the doctrine ought to be rejected, on the received axiom, that no more caufes fhould be admitted in phyfics than what are true, and fufficient to account for the phænomena.

I alfo fuggefted the propriety of philofophers turning their attention to the determining the maffes or volumes of heat neceffary to produce the various effects and changes which that fubftance operates upon bodies, inftead of contenting themfelves with fpeaking of degrees, to which they annex no correct idea; and expreffed a hope that, at no very diftant period, this improvement might be expected in fcience.

In venturing to call in queftion the truth of the received doctrines, it was not my intention to depreciate the difcoveries of a Black, a Crauford, a Lavoifier, or a Cavendifh; men whofe memories will be cherifhed, while the world endures, by every lover of fcience. Their genius, their perfevering induftry, their penetrating judgment, firft brought to view thofe luminous facts which muft ferve as the bafis of all true theory refpecting the fubjects of which they treated; and thofe facts will remain, whatever may be the fate of theories already eftablifhed, or of others that may fuperfede them.

But as truths, once eftablifhed, become a common property in fcience, thofe whofe genius would never have difcovered are not debarred the ufe of them. It may alfo be obferved, that the original difcoverers of important facts have often, in drawing their inferences and making their deductions, given an undue weight to confiderations that were no other way connected with the fubject than by being unfortunately ftumbled over in fome part of the journey, in which they chanced to be out of the right road; for who, that firft explores an unknown region, can be expected to get on without interruption or impediment? Such accidents, however, have an unavoidable influence on the nind; and to exempt any man from their confequences, when they occur, would be to deny that he is human.

Thofe who are not aware of the difficulties of this lind with which genius has to encounter, can never rightly appreciate the merits of thofe who, in fite of their influence, give 
an unbiafled account of the facts they difcover. It is one of the greatelt efforts of human probity to give them undifguifed, unwarped by theory. This praife is due to the men to whom $I$ have alluded : their labours, therefore, are invaluable, even if it thould be proved that, in fome few inftances, they have been miftaken in their inferences.

It was my intention, in addition to the facts generally mentioned in my former effay, to have brought forward, on the prefent occafion, a number of further evidences of the fubftantiality of heat; but my ftate of health, fince our laft feffion, has been fuch that $I$ have not been able to go into a wide field. I fhall, however, bring to the recollection of the Society a few well-known facts, which, according to my view of them, ferve to prove that heat is a fubftance $f u i$ generis.

Volume, as I frequently had occafion to notice in my former effay, is a characteriftic of matter; but liquids, on being mixed, are reduced in volume, without parting with any thing except heat-therefore heat is matter.

The fame effects take place when gafes are prefented to any fubftances to which they can unite. Thus, muriatic acid gas eafily combines with ice cold water; but in doing fo it parts with its heat, which forms the greateft part of its volume. The gas is in fact decompofed : one of its principles, the muriatic acid, joins the water, and its other, the heat, being thus feparated from its former affociate, then, according to the general law, firft heats the fubftances neareft to it, the acidulated water and the containing veffel, and afterwards paffes off to furrounding objects till equilibrium is reftored. If ice, inftead of water, be prefented to this gas, it will be melted by it as fpeedily as if thrown into the fire.

If certain gafes be united, this diminution of volume, this paffing off of matter, (which, though in union in the ingredients, finds the capacity of the new compound for it fo different that it muft diffufe itfelf, is, if poffible, ftill more friking When, for example, oxygen gas and nitrous gas, in the proportions neceffary to form nitrous acid, are prefented to each other, in a bell-glafs, over water, what an abridgement 
abridgment of volume takes place! It cannot be otherwife, the capacity of the new compound for heat being fo much lefs than the fum of that of the ingredients; for the moleculæ now refpectively arrange themfelves with each other in fuch a manner, that they can afford buit a fmall quantity or lodging-room for the heat, compared with what it occupied in the gafes; and it is therefore forced, by the general law, to diffufe itfelf among and through the contiguous bodies till each is with each in equilibrium. But each thereby receives an increafe of volume, that is, an increafe of matter; and it is extremely probable that, if we could get at the fum of their increafe, it would be found exactly equal to the difference between the volume of the gafes before mixture and that of the acid produced.

If any quantity of nitrous gas be joined to twice its bulk of atmofpheric air, we all know that the fame effects take place as in the cafe juft mentioned; that is, the fubftance beat changes its affociates.

We may obferve here that, as heat paffes freely through all bodies, and tends to an equilibrium; and as this equilibrium, when eftablithed in any fyftem of bodies, is fometimes higher than at others, it feems far from being correct to talk of heat being then in a fate of confinement. If a colder body be made one of this fyftem it will foon be feen that the heat, inftead of being latent in the other bodies, finds itfelf free to pafs from them into the colder body till it has received the portion fuited to its capacity compared with that of the others.

If there be any ftate in which heat is lefs in a ftate of confinement than another, it is when in equilibrium; and it is only when it has, by any means, been accumulated in individual bodies, in greater proportion than, by their capacity, compared with that of the furrounding bodies, they ought to be fupplied with, that any thing like reftraint can be confidered as impofed upon it. The impediments that retard its equal diffufion, are, in fact, the only reftraints it experiences; and to me this appears fo obyious, that I cannot help wondering how men of fcience thould ever have thought of calling it free in fuch circumftances. It is free, to be fure, but not in their fenfe of the word, for it has reftraints to overcome; but Vor. IX. 
when in equilibrium it fuffers no reftraint whatever, for then every individual fubfance has its own proper quantity of the common ftock.

I thall now examine for a little feveral facts which appear to prove, if duly weighed and applied, that heat poffeffes another characteriftic of matter, I mean GRAVITY. If this fact can be eftablithed, we thall have another ftrong proof of the fubftantiality of heat; and the facts I mean to bring to your recollection are, I think, fufficient to eftablifh it as a truth-a truth which has been forcing itfelf on the notice of men, for many centuries, with much ftronger evidence than many others which have received general admiffion, though it has not only been overlooked, but many experiments have been brought forward to eftablinh the oppofite.

Heat poured into bodies leffens their fpecific gravity; and yet heat may not be weighed, even comparatively!! There appears to me to be fomething fo extremely repugnant to reafon in this affertion, that ever fince $I$ have dared to reafon for myfelf $I$ have found myfelf forced to refufe my affent to it. If heat leffens the fpecific gravity of bodies, (and we can even determine, in many cafes, the ratio in which this takes place,) I think we are then weighing the heat itfelf, or, rather, the difference of the quantity in a body at one temperature and at another.

In the various direct attempts that have been made to weigh heat, I fear philofophers have been following a plan juft about as rational as it would be in the inhabitants of the ocean to attempt to weigh water by employing a balance fufpended in the medium that furrounds them, and putting into one fhell a fubftance that to them fhould feem wet, and into the other a fubftance which they might call dry!

If we could abftract heat entirely from a body, as we can air from a glafs balloon, we thould be at no lofs in weighing it : but is there no other way of weighing air but that one? If I take a bladder containing an unknown quantity of air, I eafily find out how much weight is required to fink it in water : if I afterwards pour into the bladder a known bulk of air, I can come at a knowledge of the weight of the air fo added by attending to the quantity of weight now neceffary 
to fink the bladder in the water, the fiecific gravity of the water being known. But if $I$ weigh, in water, any fubftance containing an unknown quantity of heat, and find that, upon adding a known bulk of heat to the body, it will then require a lefs weight to make it fink, I am to draw no inference refpecting the weight of the caloric that has been added!! Is this reafonable? Should philofophers ftop fhort in this manner, and not feize upon the truth which fuch effects exhibit to them? Is it not obvious, in all experiments which have for their object the determining the fpecific gravity of any body in different temperatures, that they are doing nothing but weighing,comparative quantities of heat, by obferving how much water is difplaced by thofe quantities?

Though I think the truth I have juft ftated is felf-evident, I hope I thall not be thought tirefome if I endeavour to fet it in a clear point of view by an illuitration.

If I fufpend a piece of metal in water at one end of a balance, and if to this n.etal $I$ join a fmall bit of any fubftance lighter than water, fay a bit of cork, will not the mafs, by having its abfolute gravity increafed, have become fpecifically lighter? I am now confidering the metal and cork as one compound body. In this cafe no one hefitates in admitting that the addition of the cork, though poffeffing abfolute gravity, is the caufe of the compound body appearing lighter when weighed in water; a medium more rare than one of the ingredients, but denfer than the other : but if beat inflead of cork bad been added to the metal, would not the effect bave been the fame, an increale of volume and a diminution of fpecific gravity? And for the fame reafon too, the metal being heavier but the heat lighter than water.

Let us reverfe the cafe $-\mathrm{A}$ compound body, iron and cork, poffeffes a certain fpecific gravity. Remove the cork, that is, take away from the mals a portion of its abfolute bulk and weight, and on weighing what remains it is found to be increafed in weight-in water.

Yet, if I detach from a piece of gold, flver, platina, copper, a certain quantity of heat, by mechanical means, and thereby reduce its volume, I am not to conclude, though I find its fpecific gravity increafed, that the matter expreffed poffeffed 
abfolute gravity, though lefs fpecifically than that of water! Is this confiftent with found phyfical principles? I think not: for the fame effects thould always be afcribed to one caufe.

It is admitted on all hands that caft metals, that is, metals n their largeft natural volume, are fpecifically lighter than when drawn into wire or rolled into plates, that is, when reduced in fize, by having fomething feparated from them, namely, heat.

If a piece of denfe wood, that has been foaked in oil or alcohol, be weighed in water; and if a portion of the imbibed liquid be expreffed, and the wood be again weighed, its fpecific gravity will be found to have increafed; becaufe the fluid expelled from it was lighter than water. Every one can fee and $f e \varepsilon l$ the oil or alcohol driven out of union with the wood; and every one may feel the heat driven out of metals by paffing them through rollers. Is it becaufe heat is only cognifable, in the firft inftance, by one grofs fenfe that its exiftence as matter is denied? It may be feen as well as felt, as I have before had occafion to remark; for when driven from one body, the volume of which is in confequence diminifhed, it enters into others, and theirs become vifibly enlarged. If it were not fo, even the common thermometer could have no exiftence.

I thall here mention the different fpecific gravities of a few metals in their caft ftate, and when a portion of heat has been feparated from them, by their moleculæ being brought fo much clofer together, by mechanical means, as to increafe the power of aggregation, or, in other words, to diminifh their capacity for heat.

$\begin{array}{lrccc}\text { Caft. } & \text { Hammered. } & \text { Rolled. } & \text { Drawn into wire. } \\ \text { Pure gold } & 192,5^{8} & 193^{62} & & \\ \text { Standard gold } & 17486 & 175^{89} & & \\ \text { Pure filver } & 10474 & 105^{11} & & \\ \text { Pure platina } & 19500 & 20377 & 22069 & 21042 \\ \text { Copper - } & 7788 & & & 8878 \\ \text { Brafs - } & 8396 & & & 8544\end{array}$

The fact is, I fufpect, univerfally true, that where the fpecific gravity of a body is diminifhed, its abfolute gravity is and mult be increafed; and thefe terms ought always to be confidered 
confidered as convertible. When a diminution of the fpecific gravity is declared, an increafe of the abfolute gravity is by the fame enunciation afferted, whether the fpeaker means to do fo or not. Now, in the cafe before ftated, the diminution of the fpecific gravity is admitted; and therefore a queftion naturally prefents itfelf-Why has the increafe of ablolute weight not been hitherto obferved? I take the reafon to be this: they attempted to determine it in the air ; overlooking this plain fact, namely, that air may be confidered as bearing the fame relation to heat that water does to gold, or rather, to a fubftance many times heavier, if fuch contd be found; that is, the air, though a rarer fubftance than the folid bodies weighed in it, is a denfer one than heat; and they have been demanding, that a fubftance fpecifically lighter than air thould defcend in it, In other words : that the laws of nature fhould be inverted, and that the heavier fluid, air, fhould afcend to make room for a lighter one, heat, to defcend.

But Nature will not bend to our whims and fancies. We muft court her, and take her as the is, or remain in error. The heated body, though increafed in fize, remains in equilibrium in the balance; and it ought to do fo (if not to afcend), being buoyed up by a greater quantity of air than before it was heated. But is this the only cafe in which that effect takes place, and where we know at the fame time that not only volume but real fubftance is added to one end of the beam? No: a bladder capable of eafily containing a gallon of air will always weigh the fame (in air) whether you put into it a pint, a quart, or a gallon.

Aye, fays a caviller, but you have not put into the bladder any thing heavier than the furrounding medium, though you have put in a real gravitating fubftance; therefore the bladder cannot weigh heavier. Inftead of anfwering him, I thall leave him to his own meditations.

Are philofophers always to continue in the belief that bodies can be made fpecifically lighter and heavier at pleafure, without any thing being either abftracted or added? Can a nonentity produce the effects of which we have been fpeaking? or, is gravity itfelf a nonentity? It either is, or 
heat is material. But, when I confider the rapid advances that have been made in various branches of fcience within thefe few years paft, I cannot allow myfelf to believe that its votaries will much longer doubt of the exiftence of the moft powerful and moft generally diffufed fubftance in nature, or long remain of the opinion, "that all attempts to difcover any effect of beat upon the apparent weigbt of bodies will be fruitlefs."

The ingenious philofopher (Count Rumford) whofe words I have juft quoted, and to whom every inquirer into Nature nuft feel himfelf highly indebted for the unwearied patience with which he has watched and traced her fteps in many of her moft intricate operations, and for the zeal which he has manifefted in applying fcientific truths to the common purpofes of life, will be among the firt to abandon the opinion; for, when he thall have better confidered the fubject, he will find the evidence lies wholly on the other fide. If the opinions I have controverted were held only by men, like him, enfightened and candid, I hould be fanguine enough to believe that what I have advanced would fuffice to convince all of their abfurdity without the neceffity of faying a word more on the fubject: bur we know well how difficult it is for the human mind to thake off imbibed prejudices, efpecially when they have been theorifed, and applied, like the falt, fulphur, and mercury, of the alchemifts, and the phlogifton of the Stahlians, to explain all the phænomena of nature; and therefore I cannot promife myfelf, that the mere treaders in trammels and day-labourers in fcience will adopt my ideas without fomething more level to their capacity being firft offered in addition to the evidence already produced. Indeed it would be unreafonable to expect that men of the caft to which I now allude hould at one glance perceive the force of truth when prefented to their view. If they ever apprehend truth, it is when it chances to be a part of the fyftem they have been taught; and that fyftem, however falfe, they always adhere to, till every perfon of fuperior intellect has abandoned it.

With a Society, however, inftituted for purpofes like ours, truth will meet with a proper reception. Thofe who are affociated 
affociated for the exprefs purpofe of exploring philofophical facts, will ever lend a ready hand to feparate the fine from the drofs; and, I doubt not, will by their labours give form and folidity to the fructure for which I have humbly endeavoured to collect a few materials.

I intended, before concluding thefe remarks, to offer a few experiments for the confideration of the Society, which, if properly conducted, would, I perfuade myfelf, furnifh direct evidence of the gravitating power or property belonging to heat in common with other kinds of matter: I confider the point as eftablifhed by the arguments already advanced, but I mean to fay, that, by certain experiments, (if I have been under no miftake in the reafoning that led me to frame them) its abfolute weight, in certain fpecific cafes', may, I think, be afcertained; but having run the prefent effay to a greater length, and encroached further upon the time of the Society than was perhaps proper, I fhall referve them for a fupplement, which I may offer hereafter, or perhaps make them the fubject of a future effay.

XXI. Account of the Manner in wubich the Tartars and Kalmuks make their Kunis, or fermented Mare's Milk*.

$\mathbf{T}$

A KE of mare's milk of one day any quantity; add to it a fixth part of water, an eighth part of the foureft cow's milk that can be got, but at a future period a fmaller portion of kumis will better anfwer the purpofe of fouring; cover the veffel with a thick cloth, and fet it in a place of moderate warmth, leaving it to reft for twenty-four hours; at the end of which the milk will have become four, and a thick fubftance gathered at top: then with a ftick, made at the lower end in the manner of a churn ftaff, beat it till the thick fubftance above mentioned be blended intimately with the fubjacent fluid: let it reft twenty-four hours in a high narrow veffel like a churn. The agitation muft be repeated as before, till the liquor appears to be perfectly homogeneous; and in this fate it is called kumis (or koumis), of which the tafte

* From Eton's Survey of tbe Turkifh Empire. 